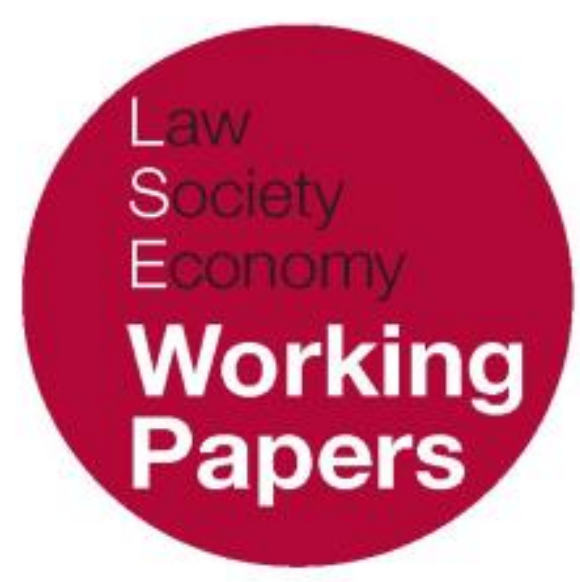

\title{
The Non-Frustration Rule and the Mandatory Bid Rule - Cornerstones of European Takeover Law?
}

\author{
Mathias Habersack \\ LSE Law, Society and Economy Working Papers 9/2017 \\ London School of Economics and Political Science \\ Law Department
}

This paper can be downloaded without charge from LSE Law, Society and Economy Working Papers at: www.lse.ac.uk/collections/law/wps/wps.htm and the Social Sciences Research Network electronic library at: https://papers.ssrn.com/sol3/papers.cfm?abstract_id= 2980321.

(C) Mathias Habersack. Users may download and/or print one copy to facilitate their private study or for non-commercial research. Users may not engage in further distribution of this material or use it for any profit-making activities or any other form of commercial gain. 


\title{
The Non-Frustration Rule and the Mandatory Bid Rule - Cornerstones of European Takeover Law?
}

\author{
Mathias Habersack *
}

\begin{abstract}
With the non-frustration rule ("NFR") and the mandatory bid rule, the Takeover Bid Directive contains two principles which have strongly influenced British takeover law for approximately 50 years. However, the changes of the economic and legal framework of the market for corporate control which have occurred since the adoption of the Directive call into question the legitimacy of both principles. Although the NFR is capable of disciplining board members, it generates misguided incentives and is, at the most, suitable as a disciplining tool of last resort. The idea that in the alternative we would rely on increasing shareholder activism and of trusting the shareholders to discipline the board (also in a company with dispersed ownership) is compelling in principle; however, as active shareholders often seek the shortterm maximisation of returns, misguided incentives cannot be avoided in this context either. In view of these findings, the article explores the ways of structuring NFR optionality. It submits that only the shareholders should be given the option of opting out of the strict NFR - which would continue to serve as the default rule - and that such an opt out should only be possible for a limited period of time. With respect to the mandatory bid rule, its justification is becoming increasingly difficult since the exploitation of the offeree company by the controlling shareholder is more or less excluded by obligations to disclose information, by shareholder activism and by the reform of the Shareholder Rights Directive. In view of the foregoing, this paper argues for reform of the Directive's mandatory bid rule, making it a mere default rule.
\end{abstract}

\footnotetext{
${ }^{*}$ Visiting Scholar, London School of Economics and Political Science; Professor Dr., Chair of Private and Business Law, Faculty of Law, Ludwig-Maximilian-University, Munich, Germany.
} 


\section{THE STATUS QUO}

\section{The Path to the Takeover Directive}

The adoption of the Takeover Bid Directive ("TBD") of 21 April 20041, about 13 years ago, represented the realisation of a project which can be dated back to the 1970s. The "Report on takeover and other bids" prepared by Robert Pennington constituted the starting point. ${ }^{2}$ It was published in 1974 and proximate in time to when the United Kingdom joined the European Economic Community, which until then only consisted of the six founding member states. At the time, the City could not only look back on several years of experience with the (First) City Code on Takeover and Mergers from the year 1968; but in addition, the Code itself was based on, the then still salient, experiences with "hostile" takeovers in the 1950s and 60s, as well as on the Notes on Amalgamations of British Businesses from the year 1959, which were introduced as a result of the events in the $1950 \mathrm{~s}^{3}$

The fact that thirty years went by until the adoption of the Directive is - not least - attributable to the fact that the very shareholder-friendly approach of British takeover law was met with little approval in continental Europe. It is a telling fact that in Germany not only the - ultimately unsuccessful - attempt of a takeover of Continental by Pirelli and the - successful - takeover of Hoesch by Krupp, but also the takeover of Mannesmann by Vodafone sealed in February 2000 - a transaction with a volume of almost 200 billion US dollars! - could take place without any binding regulation by takeover law. "Guidelines with regard to public voluntary purchase and exchange offers" (Leitsätze für öffentliche freiwillige Kauf- und Umtauschangebote) had been in existence since 1979, and a takeover code had been in place since 1 October $1995 .{ }^{4}$ Both sets of rules, however, were developed by the Stock Exchange Expert Commission (Börsensachverständigenkommission) at the Federal Ministry of Finance, and relied on the voluntary observance by the players - a concept which, in contrast to the United Kingdom - did not ensure compliance.

\footnotetext{
${ }^{1}$ Directive 2004/25/EC of the European Parliament and of the Council of 21 April 2004 on takeover bids, OJ 2004 L 142/12 of 30 April 2004.

${ }^{2}$ Comm. Doc. XI/56/74; in this regard from a German perspective, Behrens, Rechtspolitische Grundsatzfragen zu einer Europäischen Regelung für Übernahmeangebote, 4 Zeitschrift für Unternehmens- und Gesellschaftsrecht (ZGR) (1975) pp. 433 et seqq.; Bess, Eine europäische Regelung für Übernahmeangebote 21 Die Aktiengesellschaft (AG) (1976), pp. 169 et seqq., 206 et seqq.

${ }^{3}$ For more detail, see D. Kershaw, Principles of Takeover Regulation (Oxford 2016), pp. 65 et seqq.

${ }^{4}$ Original version of the Code printed in 40 Die Aktiengesellschaft (1995) p. 572; version of 1 January 1998 printed in 43 Die Aktiengesellschaft (1998) p. 133; in more detail, Assmann, Verhaltensregeln für freiwillige öffentliche Übernahmeangebote, $40 A G$ (1995) pp. 563 et seqq.; Pötzsch in Assmann/Pötzsch/Schneider, Wp̈̈G, 2nd ed. (Cologne 2013) para. 19 et seqq.
} 
Although as of February 1999, the Stock Exchange Expert Commission had already recommended the regulation of takeover bids by law, ${ }^{5}$ it was the Mannesmann takeover which encouraged the adoption of the German Securities Acquisition and Takeover Act (Wertpapiererwerbs- und Übernabmegesetz - "WpÜG") of 20 December 2001. ${ }^{6}$ However, from the beginning the "spirit" of the WpÜG differed from that of the City Code. The Notes on Amalgamations of British Businesses and thereafter the Code on Takeovers and Mergers - not least due to the influence of the players involved in creating the Code and the Panel ${ }^{7}$ - were reactions to the defences deployed against "hostile" takeover bids and resulted, most importantly, in the introduction of the non-frustration rule. ${ }^{8}$ In contrast, German law - as did the law of Delaware9 before it - took a different path, by abolishing - by means of the reform law of 1998 - takeover barriers rooted in stock corporation law, such as, in particular, maximum and multiple voting rights. ${ }^{10}$ Although the takeover law provided a non-frustration rule, stipulated in \33 of the WpÜG, it has been continuously watered down in the course of the legislative procedure, resulting in a rule that declares legal such actions of the management board which were approved by the supervisory board of the offeree company.

The "Mannesmann trauma" and the provision of $\ 33$ of the WpÜG influenced the fate of the Takeover Directive in a decisive manner. As is known, a political agreement between the Member States had been reached in 1999 with regard to the mandatory bid rule ("MBR") - which at first had been harshly

\footnotetext{
5 Pötzsch in Assmann et al., supra note 4, Introduction para. 22.

${ }^{6}$ Art. 1 German Act regulating public offers to acquire securities and company takeovers of 20 December 2001, BGBl. I p. 3822.

${ }^{7}$ Specifically in this regard Armour/Skeel, Who Writes the Rules for Hostile Takeovers, and Why? - The Peculiar Divergence of U.S. and U.K. Takeover Regulation, 95 Georgetown Law Journal (2007) 1727, 1767 et seqq. (institutional investors); Kershaw, supra note 3, pp. 85 et seqq. (merchant bankers).

${ }^{8}$ With regard to the genesis of the City Code, in general, and with regard to the origins of the NFR in the preceding hostile bids for the Savoy Hotel Company and for British Aluminium, in particular, cf. Armour/Skeel, supra note 7, pp. 1727, 1756 et seqq.; Kershaw, supra note 3, pp. 65 et seqq.

${ }^{9}$ For example, Time Warner v Paramout Communications, 571 A2d 1140 (Del 1989). The different development in the UK and in Delaware is even more noteworthy, as in both legal systems listed companies are typically characterised by dispersed ownership and also in the USA the hostile takeover is thought to operate as a disciplinary mechanism for management, which is the reason why among commentators the opinion was dominant, at first, that the management of the offeree company should remain passive. See Coffee, Regulating the Market for Corporate Control: A critical Assessment of the Tender Offer's Role in Corporate Governance, 84 Columbia Law Review (1984), pp. 1145, 1147 et seqq.; Kahan/Rock, How I learned to Stop Worrying and love the Pill: Adaptive Responses to Takeover Law, 69 University of Chicago Law Review (2002) pp. 871, 874 et seqq.; in more detail with regard to the development and with regard to the reasons for the discrepancy cf. Armour/Skeel, supra note 7 , pp. 1727, 1751 et seqq.

10 S 12 para. 2, 134 para. 1 sent. 2 of the German Stock Corporation Act in the version of the German Corporate Sector Supervision and Transparency Act (Gesetz zur Kontrolle und Transparenz im Unternehmensbereich) of 27 April 1998, BGBl. I, p. 786.
} 
criticised in Germany - so that the final adoption of the Directive seemed to be within reach. ${ }^{11}$ With regard to the question of the scope of the non-frustration rule ("NFR"), which was disputed until the very end, the supporters of a strict regime seemed to have prevailed: Pursuant to Art. 9 para. 1 lit. (a) of the draft directive, the management board of the offeree company was to be obliged, as a general rule, to obtain prior authorisation from the general meeting before taking any action which may result in the frustration of the bid. Different rules were to apply only to the search for competing bids and to the utilisation of an authorised capital.

Irrespective of the compromise worked out by the conciliation committee, however, Art. 9 of the draft directive, in particular, was met with fierce resistance from the Federal Republic of Germany. A key concern was that the defensive means provided for in the articles of association, which were taken away from German companies by the aforementioned reform of 1998, were still available to those companies which had their registered office in other member states. After the Federal Government had been successful in mobilising - in addition to the German parliamentarians - also the parliamentarians of Italy and Spain accordingly, the proposal for a directive did not win the necessary majority for a resolution adopting the Directive by the European Parliament on 4 July 2001.

The Commission, however, did not give up and, not least encouraged by the ECJ judgements delivered with regard to 'golden shares', ${ }^{12}$ submitted a new proposal for a takeover directive on 2 October $2002,{ }^{13}$ which - inspired by the observations and recommendation of the of the High Level Group of Company Law Experts ${ }^{14}$ - contained a strict NFR and a breakthrough rule ("BTR") with regard to restrictions on voting rights and on disposition provided for in the articles of association. After it became apparent that this would also be met with resistance from a few member states, ${ }^{15}$ a compromise with regard to the particularly sensitive questions of the NFR and the BTR was reached at the initiative of Portugal at the beginning of June 2003 in the form of the option model provided for in Art. 12 of the TBD. However, the Commission was able to

${ }^{11}$ Neye, Die EU-Übernahmerichtlinie auf der Zielgeraden, 22 Zeitschrift für Wirtschaftsrecht (ZIP) (2001), p. 1120: EU Takeover Directive getting to the finish line.

12 ECJ, Case C-483/99, 2002 I-4781; ECJ, Case C-367/98, 2002 I-4731.

13 Printed in 23 ZIP (2002), pp. 1863 et seqq.; in this regard Habersack, Reformbedarf im Übernahmerecht!, 166 Zeitschrift für das gesamte Handelsrecht und Wirtschaftsrecht (ZHR) (2002), pp. 619 et seqq.; Krause, Der Kommissionsvorschlag für die Revitalisierung der EUÜbernahmerichtlinie 57 Betriebs-Berater (BB) (2002), pp. 2341 et seqq.; Seibt/Heiser, Der neue Vorschlag einer EU-Übernahmerichtlinie und das deutsche Übernahmerecht, 23 ZIP (2002), pp. 2193 et seqq.

${ }_{14}$ Report of the High Level Group of Company Law Experts on issues related to takeover bids, Brüssel, 10. January 2001; in this respect cf., in particular, Wiesner, 23 ZIP (2002), pp. 208 et seqq.

15 This was caused by the fact that the breakthrough rule of Art. 11 of the proposal was intended to apply to restrictions on dispositions and on voting rights, but not to the multiple voting rights which are especially popular in Scandinavia; cf. Wiesner, supra note 14, p. 967. 
maintain the mandatory bid rule ("MBR") as a mandatory requirement - an outcome that was surely enabled by the fact that the takeover laws of most of the member states had already followed the example of the City Code in adopting an MBR. ${ }^{16}$ However, although mandatory Art. 5 of the TBD provides significant scope for the member states with regard to the structuring of the MBR. This applies, in particular, with regard to the threshold of voting rights which confers "control" and the method of its calculation, but also with regard to the reference period, which is relevant to the determination of the highest price paid for the same securities, as well as to the kind of consideration. Furthermore, the Directive allowed for exceptions from the MBR to be provided for by the member states.

\section{APPLICATION REPORT OF THE COMMISSION}

\section{a) Measures Considered by the Commission}

In 2007, the Commission submitted a report on the implementation of the Directive in the member states, which concluded - hardly surprising due to the many options for the member states - that the member states had essentially kept the previously existing takeover barriers, and in some case even increased them. ${ }^{17}$ In light of the revision clause of Art. 20 of the Directive, the Commission - based on an "Assessment Report" which Marcuus Partners was commissioned to prepare by the Commission" - then published its "Application Report" on 28 June $2012 .{ }^{19}$ Pursuant to this report, while 19 member states had transposed the NFR (Art. 9, TBD), only three member states (namely Estonia, Latvia and Lithuania) had transposed the BTR (Art. 11, TBD). About half of the member states made use of the reciprocity clause in Art. 12 para. 3 of the Directive which allows companies which are subject to the NFR and/or the BTR ${ }^{20}$ not to apply these provisions, if the offeror or any company controlled by the offeror is not bound by them. ${ }^{21}$

\footnotetext{
${ }^{16}$ Hopt, European Takeover Law (Tübingen 2013), p. 32. For the development cf. under IV. 1.

${ }^{17}$ Commission Staff Working Document, Report on the Implementation of the Directive on Takeover Bids, 21. 2. 2007, SEC (2007) 268; in this regard, Davies/Schuster/v. d. Walle de Ghelcke, The Takeover Directive as a Protectionist Tool?, ECGI Law Working Paper N. 141/2010, pp. 33 et seqq., 48 et seqq.

18 The Takeover Bids Directive Assessment Report, commissioned by the European Commission and published on 28/6/2012. This Assessment Report is a study which consists (without annexes) of 367 pages and which has an empirical and comparative legal approach; it was prepared in co-operation with the Centre for European Policy Studies and takes into account the takeover laws of $22 \mathrm{EU}$ Member States as well as of some third-party countries (in particular, the USA and Switzerland).

19 European Commission, Report from the Commission to the European Parliament, the Council, the European Economic and Social Committee and the Committee of the Regions, Application of the Directive 2004/25/EC on takeover bids, COM (2012) 347 final.

${ }^{20} \mathrm{Be}$ it, because no opt-out of the member state pursuant to Art. 12 para. 1 exists, be it, because the company decided to opt in pursuant to Art. 12 para. 2.

${ }^{21}$ With regard to the relationship towards third countries cf. Recital 21 as well as in detail, Kersting, Die Reziprozitätsregel im europäischen Übernahmerecht und ihre Anwendung auf
} 
Although the Commission was of the opinion that 'the regime created by the Directive is working satisfactory' and that 'no structural compliance issues have emerged in relation to the application of the legal framework in the Member States', the Commission identified five areas, in which 'the rules of the Takeover Bids Directive could merit some clarification in order to improve legal certainty for the parties concerned and the effective exercise of (minority) shareholder rights'.22 In addition to a further clarification of the wording of the requirement of 'acting in concert', further examination was recommended with regard to the exceptions from the MBR and the continuation of the dialogue with employee representatives with regard to the development of a better protection of employees. In addition, the Commission was also concerned about a "low balling" technique for evading the application of the MBR:

Thirdly, the review shows that the exemption to the mandatory bid rule included in the Takeover Bids Directive, for situations where control has been acquired following a voluntary bid for all shares of the company, has created a possibility for offerors to get around the mandatory bid rule by acquiring a stake close to the mandatory bid threshold and then launching a voluntary bid for a low price. As a consequence, the offeror would cross the mandatory bid threshold without giving minority shareholders a fair chance to exit the company and share in the control premium. This technique is clearly not in line with the objective of the Directive to protect minority shareholders in situations of change of control, although it does not appear to breach the letter of the Directive. Examples in national legislation, such as additional mandatory bid thresholds or minimum acceptance conditions to takeover offers, show that there are possibilities to prevent the use of this technique. The Commission will take the appropriate steps to discourage the use of this technique across the EU, such as through bilateral discussions with the concerned Member States or Commission Recommendations. ${ }^{23}$

With regard to the NFT and BTR, the Commission at this stage considered that is was 'not ... appropriate' to abolish the options contained in Art. 12 of the Directive with regard to the NFR (Art. 9) and the BTR (Art. 11) and to transform the respective provisions into mandatory provisions. However, it observed, 'the lack of application of the optional rules does not seem to have been a major obstacle to takeover bids in the EU, given that stakeholders have indicated that there are sufficient possibilities to break through takeover defences. ${ }^{2} 4$

Gesellschaften aus Drittstaaten 18 Zeitschrift für Europäisches Wirtschaftsrecht (EuZW) (2007), pp.

528 et seqq.; further, Davies/Schuster/de Ghelcke, supra note 17, p. 24.

${ }^{22}$ European Commission, supra note 19, paras. 21 et seqq.

23 Ibid., para. 25.

24 Ibid., para. 26. 


\section{b) No Changes with Regard to the Non-Frustration Rule and Breakthrough Rule}

In particular, the findings of the Commission with regard to the options in Art. 12 of the Directive clearly indicate that one can no longer expect a revitalisation of the ambitious harmonisation plans from the time prior to the adoption of the Directive, let alone a transition to full harmonisation. ${ }^{25}$ It will, therefore, continue to be left to the member states to decide on the application of the non-frustration rule and the breakthrough rule. A member state that decides against the application of the aforementioned principles, must grant to the shareholders the option to apply the aforementioned provisions anyway; and the reciprocity rule of Art. 12 para. 3 of the TBD already mentioned above also continues to apply. However, the creation of a "level playing field" with regard to the non-frustration rule and the breakthrough rule is no longer sought after. Therefore, takeover law, although it ultimately has a hybrid character, which does not only include company law, but also and foremost capital market law elements, shares the fate of European company law, with regard to which - after ambitious and promising attempts especially in the 1970s and 1980s - we have arrived at an almost complete standstill in relation to harmonisation. In contrast, ${ }^{26}$ capital markets law is characterised by an almost comprehensive harmonisation, whose shining star is without doubt the Market Abuse Regulation, which is directly applicable.

The Commission cannot be held responsible for the standstill. Any attempts at making the Takeover Directive more strict, such as the transition to a mandatory non-frustration rule or even a mandatory breakthrough rule, currently do not fit into the political landscape (in other words, they would have no chance of being implemented). As early as 2011, Enriques concluded that 'national government's protectionist instincts have, if anything, strengthened since 2004';27 since then, this trend has rather increased. To complicate matters further, with Brexit the very member state which is seen by many to offer model takeover regulation with both a mandatory NFR and MBR will leave the European Union and will, therefore, loose its influence over EU law. 28

\footnotetext{
${ }^{25}$ Similar conclusions in Hopt, supra note 16, pp. 20 et seqq.

26 One only needs to consider that the project of a reform of the Shareholder Rights Directive, which is rather modest measured by the great "successes" of the Directives on Public Disclosure, Capital and Cross-Border Mergers, started with a Commission proposal from the year 2014 and that an agreement with the Council and the Parliament could not be achieved prior to December 2016, cf. in this regard under III. 1. b.

${ }_{27}$ Enriques, European Takeover Law: Designing a Neutral Approach, Festschrift für Klaus J. Hopt, (Berlin 2010), pp. 1789, 1790.

${ }^{28}$ In this regard as well as with regard to the criticism of a strict non-frustration rule, which is rising amongst English legal commentators due to the experience with Cadbury/Kraft cf. under III.
} 


\section{THE KEY ISSUE: APPROPRIATE DIVISION OF LABOUR BETWEEN COMPANY LAW AND TAKEOVER LAW}

\section{THE NON-FRUSTRATION RULE AND THE MANDATORY BID RULE IN THE LIGHT OF CHANGED CIRCUMSTANCES}

The Takeover Directive did result in substantial harmonisation of takeover law in particular with regard to the process of takeover bids, the disclosure obligations of the offeror, the squeeze-out and sell-out as well as the MBR. The initial aim of the Commission to create a level playing field and to ensure an even balance between the shareholders and the management of the offeree company was ultimately not achieved, given the optional NFR. Davies/Schuster/de Ghelcke even raise the question whether the TBD ends up being a 'protectionist tool'. At the end of their study they conclude that 'instead of facilitating the Commission's ideal of a comprehensive, mandatory board neutrality rule, the Directive has, in aggregate, likely had an opposite effect' and 'that there are signs of protectionist motives driving member states' choices regarding board neutrality'. ${ }^{29}$

This result can hardly be denied, however, the question remains, whether one should complain about this outcome. Should it be lamented that there is no strict NFR that requires EU-wide application, given that US takeover law manages well without any NFR? Does it constitute a shortcoming that the MBR lacks clear requirements, in particular with regard to the control threshold, and that instead it shifts the task of stipulating the control requirements and the method of their determination to the member states? Does it really give cause for complaint that the MBR does allow low-balling even if it is true that such conduct 'is clearly not in line with the objective of the Directive to protect minority shareholders in situations of change of control', so that - in this regard - there is a need for a reform of the TBD?

The answer to these questions not only requires us to revisit the fundamental principles of takeover and company law, but makes it necessary, in addition thereto, to take into account the changes in market and regulatory context within which takeover regulation applies, which has occurred or been compounded since the adoption of the TBD. ${ }^{30}$ Such changes include in addition to the advanced harmonisation of capital markets law: the rapidly changing modalities of securities trading; the increasing importance of institutional investors, in general, and of foreign institutional investors, in particular; the influence of proxy advisers and the widespread utilisation of contracts for difference for the purpose of building up shareholdings; Brexit and other protectionist tendencies; and regulatory initiatives such as the Directive on amending the Directive 2007/36 on the exercise of

${ }^{29}$ Davies/Schuster/de Ghelcke, supra note 17, Abstract.

${ }^{30}$ Correctly Wymeersch, A New Look at the Debate about the Takeover Directive, Festschrift for P. Hommelhoff (Cologne 2012), pp. 1375 et seqq.; Kershaw, supra note 3, pp. IX et seqq. 
certain rights of shareholders in listed companies ${ }^{31}$ ("SRD"), by which it is intended to create specific company law protective mechanisms in connection with related party transactions and, in addition, to promote shareholder activism.

With regard to this latter shareholder rights initiative, while an efficient regulation of related party transactions raises the question whether minority shareholders still need a specific takeover law protection in the form of an MBR, it is not possible to draw clear consequences with regard to the importance and fate of the NFR from sustainable shareholder activism. On the one hand, for example, it does not seem implausible to propagate participation rights in the general meeting with regard to the defence against a takeover bid, especially with reference to the changing role of shareholders; however, on the other hand, one could argue that defence powers of the management are not necessary where shareholders are able to defend themselves against too far-reaching an entrenchment of the administration.

\section{COMPANY LAW OR TAKEOVER REGULATION}

The economic circumstances of company takeovers, the need for protecting the offeree company, the shareholders and other stakeholders, including in particular the employees, and the regulatory instruments which provide this protection will not need to be discussed here in detail. ${ }^{32}$ The analysis in this section takes the following as given:

- a public takeover bid results in a "siege" of the offeree company;

- the management of the offeree company, which is confronted with a takeover bid, suffers from a significant conflict of interests;

- the shareholders of the offeree company - as addressees of the takeover bid - have a serious collective action problem;

- in the controlled company, conflicts of interest arise between the controlling shareholder and the minority shareholders; and

- the interests of the shareholders of the offeree company often diverge from the interests of the employees and that, therefore, company takeovers give rise to a specific problem of employee protection.

The key question addressed here is whether the law should react to these and comparable protection problems by means of specific takeover law provisions or

\footnotetext{
31 Directive on amending Directive 2007/36/EC as regards the encouragement of long-term shareholder engagement and Directive 2013/34/EU as regards certain elements of the corporate governance statement, Proposal of 13 December 2016, 15248/16, adopted by Council on 3 April 2017. With regard to the regulation of related party transactions cf. J. Vetter, Regelungsbedarf für Related Party Transactions?, 179 ZHR (2015) pp. 273 et seqq.; with regard to shareholder activism cf. Graßl/Nicoleyzcik, Shareholder Activism und Investor Activism, $62 A G$ (2017), pp. 49 et seqq.

${ }^{32}$ For a current overview cf. Hopt, supra note 16, pp. 2 et seqq.
} 
whether it can rely on the effectiveness of the general company law instruments (i.e. primarily on the management's duty of care and loyalty, on the company law restrictions on distributions and, as the case may be, on instruments under the law on groups of companies). In this regard, it is necessary - already from the outset to differentiate between three areas of regulation:

- To the extent that the takeover procedure, including disclosure, the requirements with regard to the making of the takeover bid and the possibilities of its acceptance are concerned (also after the expiry of the acceptance period by granting a further acceptance period, as well as after the acquisition of control by granting a sell-out right), company law instruments generally provide just as limited regulation and rely on general contract law. Specific takeover law rules are required in this regard.

- As is well known, with regard to the resolution of the conflict of interests of the incumbent management and the protection of the minority shareholders of the company that has become controlled, US law and British law and regulation take diametrically opposite paths: While the City Code on Takeover and Mergers ("City Code") works with specific takeover regulatory instruments and always had a strict NFR and an equally strict MBR, the law of Delaware along with Federal takeover process rules in the Williams Act governs most takeovers in the US and has neither an NFR nor an MBR. ${ }^{33}$ Due to the far-reaching power of the board of a US offeree company to defend against an unsolicited takeover bid, US takeover law also is able to do without specific provisions protecting the offeree company against an inappropriate "siege". In contrast, the City Code provided direct regulation of the "siege problem", mainly in the form of the strict "put up or shut up" rule. ${ }^{34}$ The TBD steers a middle course. As was already shown in the introduction, with regard to the question of the NFR, the TBD eventually did not include a mandatory provision, however, it at least contains an MBR, which according to the plans of the Commission is now to be secured against "circumvention" by low-balling strategies.

- Finally, with regard to the question whether the management of the offeror company must obtain a decision of the general meeting (of the offeror company or, if the latter is - as is often the case - a special purpose vehicle, of the parent company) prior to making a takeover bid, this question is left - both by the TBD and also by most of the national

\footnotetext{
${ }^{33}$ In more detail with regard to the City Code and to US law, cf. under III., IV. With regard to the reasons for the different development of US and British takeover law, in particular with regard to the influence of the institutional investors on the "privatisation" of the English takeover law, Armour/Skeel, supra note 7, pp. 1727, 1765 et seqq.

${ }^{34}$ In this regard cf. under III. 5.
} 
takeover laws - to the respective company law; 35 only very rarely, this question is dealt with by capital market law provisions, e.g. by Section 10 of the Listing Rules of the London Stock Exchange requiring approval for Class 1 (greater than $25 \%$ of company value) transactions. Questions are often raised as to whether this regulatory lacuna is appropriate, especially when one considers that a takeover bid affects the interests of the shareholders and stakeholders of the offeror company alike and that, according to empirical research, takeovers often result in share price losses on the part of the offeror company. ${ }^{36}$

It would go beyond the scope of this text to analyse NFR and MBR comprehensively. Instead, it shall be examined - based on the Application Report of the Commission - which role the two principles should take in the future following the substantial changes of the legal and market context, which - as was shown above - have occurred or been compounded since the adoption of the TBD.

\section{NFR - AN INDISPENSABLE PART OF CORPORATE GOVERNANCE?}

\section{MisGUIDED INCENTIVES AND CONFLICTS OF INTEREST - THE CHOICE BETWEEN SCYLLA AND CHARYBDIS}

\section{a) Disciplining Function of the NFR in a Company with Dispersed Ownership}

Public takeover bids are aimed at the acquisition of control of a listed company and are, therefore, part of the general market for companies. According to a widespread opinion, this market for companies has a dual function. Like every market, the market for corporate control is firstly also intended to ensure the optimal allocation of resources. The sub-market for the control of listed companies is, furthermore, intended to fulfil the function of disciplining the directors of the company. ${ }^{37}$ The concept is not complicated: due to the fact that in the event of a takeover of the company which is not coordinated with the directors, the directors are at risk of being dismissed by the offeror after the

\footnotetext{
35 With regard to the legal situation under German company law cf. Emmerich/Habersack, Konzernrecht, 10th ed. (Munich 2013), pp. 101 et seqq.

${ }^{36}$ Hopt, supra note 16, pp. 7 f.; Martynova/Renneboog, A Century of Corporate Takeovers: What Have we Learned and Where Do We Stand?, 32 J. of Banking \& Finance (2008), pp. 2148, 2153.

${ }^{37}$ Manne, Mergers and the Market for Corporate Control, 73 Journal of Political Economy (1965), p. 110; Coffee, supra note 9, 1145; Fama/Jensen, Separation of Ownership and Control, 26 Journal of Law and Economic (1983), p. 301; Gilson, A Structural Approach to Corporations: The Case against Defensive Tactics in Tender Offers, 33 Stanford Law Review (1981), p. 841; further ref. in Hopt, supra note 16, pp. 84 et seqq.
} 
offeror has acquired control of the company, the mere possibility of such a takeover gives them a sufficient incentive to manage the company for the benefit of the shareholders and to maintain a share price which make it unattractive for an offeror to take over the company. However, according to the supporters of a strict NFR, this incentive would be lost in the event that the directors had the opportunity to frustrate a takeover bid unwanted by them and, thereby, to remove the necessary "contestability". For proponents of this position, as a result of the fact that the directors generally do not have to be afraid of being held accountable even if their management is not very successful, the disciplining function of the market for corporate control compensates for the problem that the shareholders although entitled in theory - are in practice unable to react to ineffective management in an appropriate manner.

It is obvious that such a model may claim applicability primarily with regard to companies with dispersed ownership. ${ }^{38}$ In the event, however, that the company has an influential or even controlling shareholder, the directors must also irrespective of the possibility of a "hostile" takeover - expect counterreactions, if they do not live up to the expectations placed on them. Even if they cannot easily be dismissed early, they at least have to fear not to be reappointed after the expiry of the term of office. In these cases, there is no need for an additional disciplining instrument. In fact, where an influential or even controlling shareholder exists, typically first a sale of a block of shares takes place, which is then followed by a voluntary takeover bid or - in case of the acquisition of a block of shares which confers control - a mandatory bid of the acquirer of the block of shares. It is true that it cannot be excluded that an offeror makes a voluntary takeover bid without having made a prior arrangement with the controlling shareholder. However, it would be exceptional in such a case if the directors took defensive measures against the will of the controlling shareholder. ${ }^{39}$

\section{b) Market Imperfections and Misguided Incentives}

The fulfilment of the functions intended for the market for corporate control the optimal allocation of resources and the disciplining of the directors - can be achieved, as a matter of course, only by accepting market imperfections.

aa) Firstly, with regard to the allocation of resources, imperfections can be found everywhere. They are linked to the takeover procedure and here mainly to a

\footnotetext{
38 Davies/Schuster/de Ghelcke, supra note 17, p. 13; Hopt, supra note 16, pp. 11 et seqq.

39 Such cases cannot be ruled out completely. The recent attempt to increase the price of the takeover of Braas Monier Building Group S.A. with its registered office in Luxembourg by Standard Industries (which already held an indirect interest of 39.88\% in the offeree company) by means of the issue of "bonus shares" can be mentioned, furthermore the recent attempt of the board of directors of Sika AG, Zurich, to frustrate the takeover of the company by Compagnie de Saint Gobain, Courbevoie (France), by means of the application of a clause in the articles of association which provided for a restriction of the transferability and a maximum voting right, to the seller of a shareholding that conferred control, and to the offeror (cf. Cantonal Court Zug, Decision of 27 October 2016 - A3 2015 27).
} 
form of "free riding", i.e. as outside shareholders expect the shares to increase in value after the successful takeover, the offeror may be forced to share such future value gains by means of a respectively high (premium) bid price. ${ }^{40}$ The offeror will have to make such value transfers when there remains inescapable uncertainty as to whether the integration of the offeree company will be successful and the synergies realised.

bb) The disciplining function of the market for corporate control creates even bigger problems, because it is already questionable, whether the stock exchange price is able to reflect the management performance in a reasonable manner. ${ }^{41}$ The experiences with the comply or explain mechanism with regard to the respective corporate governance code give reason to be rather sceptical; the expectation that the market rewards "good" corporate governance and punishes "bad" corporate governance - and that, therefore, a competition arises for the best corporate governance - was, at least for the German market, not realised. ${ }^{42}$ Furthermore, if managers manage to share price in light of concerns about a possible takeover, there is real a risk that the directors will overweight measures to which they ascribe an effect that increases the share price and measures which promote job creation, but also research and development may fall by the wayside in the process. The 'contestability of control' ensured by the NFR 'is not costfree.' 43

Tellingly, the "invention" of the poison pill ${ }^{44}$ by Martin Lipton sees itself as a manifestation of an extended stakeholder approach, inspired by the experiences with the leveraged buy-outs common in the 1980s in the USA, which regularly resulted in the hiving off of parts of the company, the closing down of production facilities and the laying off of employees. ${ }^{45} \mathrm{~A}$ strict NFR, that much can definitely be said, obliges the board to adhere to a more or less pure shareholder value approach and thereby thwarts measures, including some of those which were initiated following the financial crisis, to orient the remuneration of the board

\footnotetext{
40 Fundamentally Grossmann/Hart, Takeover Bids, The Free-Rider Problem and the Theory of the Corporation, 11 Bell. J. Econ. (1980), p. 42; in this regard, Habersack/Tröger, "Ihr naht Euch wieder, schwankende Gestalten..." - Zur Frage eines europarechtlichen Gleichbehandlungsgebots beim Anteilshandel, 13 Neue Zeitschrift für Gesellschaftsrecht (NZG) (2010), p. 1, 2; further, Enriques, supra note 27, pp. 1789, 1791 et seqq. With regard to free riding $\mathrm{cf}$. under IV.2.

${ }^{41}$ In this regard already, see Manne, supra note 38, p. 110, 112: 'A fundamental premise underlying the market for corporate control is the existence of a high positive correlation between corporate managerial efficiency and the market price of shares of that company.'

${ }^{42}$ Cf. Habersack, Staatliche und halbstaatliche Eingriffe in die Unternehmensführung (Munich 2012), pp. E 52 et seqq.; Tröger, Aktionärsklagen bei nicht-publizierter Kodexabweichung, 175 ZHR (2011) p. 746 et seqq.

${ }^{43}$ Enriques, supra note 27, p. 1791.

${ }^{44}$ It grants all shareholders - with the exception of the offeror - the right to subscribe for shares of the offeree company at a reduced price pursuant to the conditions stipulated by the board in the shareholder rights plan; shareholder approval is not necessary.

${ }^{45}$ Lipton, Takeover Bids in the Target's Boardroom, 35 Business Lanyer (1979), p. 101; further, Why Martin Lipton invented the poison pill, www.youtube.com/watch?v= s0 TrZvKFCw.
} 
members towards a sustainable development of the company. ${ }^{46}$ From this perspective, it is indeed consistent that in the case of listed UK companies - which are subject to the strict NFR of the City Code - the remuneration is also provided on the basis of long-term incentive plans, but that these long-term incentive plans are typically linked to the "relative total shareholder return" or to the "earnings per share" ${ }^{47}$ It remains to be seen whether the reforms considered by the May Cabinet initiate a paradigm shift in this regard and whether - in the end - maybe even the strict NFR might become restricted. The "Corporate Governance Reform" Green Paper submitted by the Department for Business, Energy \& Industrial Strategy in November 2016 at least raises the question 'how long-term incentive plans (could) be better aligned with the long-term interests of quoted companies and shareholders', and dedicates a separate chapter to 'approaches to strengthening the stakeholder voice at board level in large UK companies, particularly the voices of employees and customers'. ${ }^{48}$ Also at the European level, increased efforts are noticeable to orient the remuneration of the board members towards the sustainable development of the company. Namely, in addition to the obligatory right of the shareholders to vote on the remuneration policy, the Directive on amending the SRD 49 provides for extensive requirements with regard to remuneration policy; it must be explained, in particular, how financial and nonfinancial performance criteria (including, where appropriate, criteria relating to corporate social responsibility) contribute to the business strategy, long-term interests and sustainability of the company. This means that - even at the level of European law - there is a relevant conflict between Art. 9 of the TBD and the SRD, which can ultimately be solved by the right to opt out provided for in Art. 12 of the TBD.

If, therefore, the NFR - more precisely: the risk posed by it that a share price that is too low results in a successful takeover bid and, as a result thereof, in the dismissal of the incumbents - creates a "transmission mechanism", which can

\footnotetext{
${ }^{46}$ With regard to German law, emphasis has to be placed, in particular, on the amendments made to $\$ \$ 87,107$ para. 3, 120 para. 4 of the German Stock Corporation Act by the German Act on the Appropriateness of Management Board Remuneration (Gesetz, zur Angemessenheit der Vorstandsvergittung) of 31 July 2009 (BGBl. I 2009, 2509); pursuant to $\ 87$ para. 2 sent. 2 and 3 of German Stock Corporation Act, the remuneration structure of listed companies must be oriented towards a sustainable development of the company; therefore, variable remuneration components are supposed to have an assessment basis that extends over several years and must contain a possibility of limitation in case of extraordinary developments; in more detail, Seibert, Die Koalitionsarbeitsgruppe „Managervergütungen“: Rechtspolitische Überlegungen zur Beschränkung der Vorstandsvergütung (Ende 2007 bis März 2009), Festscbrift für Uwe Hüffer, (Munich 2010), pp. 955 et seqq.

${ }^{47}$ In more detail, Kershaw, Company Law in Context, 2nd. ed. (Oxford 2012), pp. 291 et. seqq. (301).

${ }^{48}$ www.gov.uk/beis.

${ }^{49}$ See supra note 31.
} 
transmit short-termism into the boardroom, ${ }^{50}$ whether it does so in relation to individual companies depends on other factors, such as the influence of the shareholders - as determined by shareholder ownership structure and shareholder rights - and the remuneration of the directors, as to whether and to what extent this actually takes place. ${ }^{51}$ However, a significant risk exists, in particular, if shareholders who are interested in the achievement of share price gains or high distributions, are in a position to exert influence on the management, or if remuneration agreements are linked to short-term or medium-term target share prices. This inclination is amplified by the increasing importance of institutional investors and the fact that their administration is conducted by fund managers whose remuneration is typically oriented towards the relative success of their investment strategy and who, therefore, have every incentive to accept the takeover bid even if the price offered exceeds the stock exchange price, but is lower than the actual value of the share. ${ }^{52}$ Thus, the defensive measures of the board, which possesses insider information, do not only contribute to the protection of the shareholders from their own investment decision, ${ }^{53}$ but also and foremost to the protection of the ultimate investors from their own fund managers. ${ }^{54}$

\section{c) Conflicts of Interests of the Incumbent Directors}

If, therefore, the NFR is only partly suitable to "truly" discipline the directors, this does not have to mean that the directors should be awarded the power to take defensive measures without the participation of the shareholders. Rather, it is evident, and as such undisputed, that the directors, who are confronted with an unsolicited takeover bid, suffer from a substantial conflict of interests, which results from the very fact that in case of a successful bid the offeror may be inclined to dismiss the incumbent directors. From the point of view of the supporters of a strict NFR, the conflict of interests - and, therefore, the obligation to remain passive - is effectively "self-inflicted", because the directors proved incapable of managing the company in such a successful manner to ensure that there was no reason at all to identify the company as a takeover target.

But also irrespective of this understanding, the conflict of interest is already explained by the fact that by taking defensive measures the directors would conduct a business which primarily concerns the shareholders as addressees of the bid. Consequently, the directors should only be able to frustrate this business opportunity of their own accord, if it was ensured that the directors act in the best

\footnotetext{
${ }^{50}$ Roe, Corporate Short Termism - In the Boardroom and in the Courtroom, 68 Business Lanyer (2013), pp. 978, 985; Kershaw, supra note 3, pp. 29 et seqq.

${ }^{51}$ Roe, supra note 50, p. 985.

52 Kershaw, supra note 3, pp. 342 et seqq.

53 With regard to this aspect cf. Gilson/Kraakman, Delaware's Intermediate Standard for Defensive Tactics: Is there Substance to the Proportionality Review?, 44 The Business Lanyer (1989), p. 247.

${ }^{54}$ Kershaw, supra note 3, pp. 341 et seqq.
} 
interest of the shareholders. From the point of view of the supporters of a strict NFR, however, this cannot be presumed, which is the reason why it is consistent that the Listing Rules of the London Stock Exchange prohibit the restriction of the transferability of listed shares and, therefore, bar the company - also outside of takeover bids - from exerting influence on the transfer of shares. 55 Nevertheless, it would go too far to argue for logical reasons - based on the fact that the takeover bid is not directed at the company, but at the shareholders against a right of defence of the company, which acts through the directors. Since the bid is aimed at providing the offeror with the control of the company, the bid rather corresponds - with regard to its economic significance - to a merger than to an ordinary transfer of shares. ${ }^{56}$ There is also no need to follow the "classical" view of English company law, according to which the board members do not have original powers to dispose of company assets, but only powers to dispose of company assets which are derived from the articles of association and, thus, from the shareholders, while the respective powers of the board members of a US company are based on statutory law and are, therefore, of a genuine nature. ${ }^{57}$ This is because the specific risk that the directors make use of any defence powers in their own interest exists entirely irrespective of such "dogmatic" considerations.

This also applies to the stock corporation under German law with its two-tier system. Pursuant to $\ 111$ para. 4 sent. 2 of the German Stock Corporation Act, the management board generally needs the approval of the supervisory board in order to take defensive measures. However, this does not have a disciplining effect since the members of the supervisory board also have to fear to be dismissed once the takeover is completed. To complicate matters further, the supervisory board of a listed company is not necessarily, but regularly, subject to co-determination pursuant to the German Co-Determination Act (Mitbestimmungsgesets) or the German One-Third Participation Act (Drittelbeteiligungsgesets) 58 and, according to experience, the employee representatives oppose a takeover bid also because they fear reorganisation, cost cutting and lay-offs. As a result, however, the conflict of interest in the person of the management board is intensified.

\footnotetext{
${ }_{55}$ See Rule 2.2.4 of the Listing Rules and in this regard Kershaw, supra note 3, pp. 38 et seqq.

56 Kershaw, supra note 3, pp. 330 et seqq.; see further Davies/Hopt, Control Transactions, in Kraakman/Armour/Davies/Enriques/Hansmann/Hertig/Hopt/Kanda/Rock, Anatomy of Corporate Law, 2nd ed. (Oxford 2009), p. 228: disjunction between the parties to the dealing and the parties to the control shift itself.

${ }^{57}$ In this regard Kershaw, supra note 3, pp. 332 et seqq.

${ }^{58}$ Pursuant to $\iint 1$ para. 1, 7 para. 1 of MitbestG (German Co Determination Act), half of the members of the supervisory board of a company which group-wide ( $\ 5$ para. 1 , Mitbest $G$ ) has more than 2000 employees, are shareholder representatives and the other half are employee representatives; $\int 1$ para. 1 of DrittelbG (German One-Third Participation Act) provides that in a company with more than 500 employees one third of the supervisory board is comprised of employee representatives with, pursuant to $\ 2$ para. 2 of DrittelbG, only the employees of those controlled companies being attributed, which are connected to the parent company by means of a control agreement.
} 
Kahan/Rock pointed out, that - in practice - mechanisms have developed which give sufficient incentives for the resistant board to accept a "hostile" takeover bid which means that it is more likely that defensive means - among them, in particular, the poison pill - will be used by target boards to buy time (and bargaining power) in order to negotiate a higher price with the raider or to find a white knight, rather than to "just say no". ${ }^{59}$ According to Kahan/Rock, these mechanisms, which promote the "contestability" of the offeree company, include, in particular, remuneration agreements, but also the existence of independent directors, who do not have the same incentives as managers to resist the takeover bid. They argue that 'ultimately, the pill contributed to a new equilibrium in which it seems to have transformed into a device that plausibly is in shareholder's interests and certainly one with which shareholders can easily live. ${ }^{60}$ However, at least from the perspective of a legal system which obliges the management to observe not only the interests of the shareholders, but also the interest of the company, which includes the interests of other stakeholders, it is legitimate at least to question whether the burdening of the company's assets with generous severance payments for the benefit of incumbent board members does constitute a balanced solution. For good reason, therefore, the German Corporate Governance Code is critical - particularly in light of the substantial payments to managers arising from the takeover of Mannesmann $A G$ by Vodafone mentioned in the introduction ${ }^{61}$ - of the provision of disproportionate severance payments. ${ }^{62}$ Moreover, Davies/Schuster/de Ghelcke point out correctly that such severance payments have the character of a "reward for failure", because the takeover may have taken place because of the underperformance of the offeree company. ${ }^{63}$

\section{NO REDUNDANCY OF THE NFR}

Pursuant to the above findings, both the approach of English law and also the law of Delaware give rise to some reservations. While the strict NFR might address the board's non-aligned incentives, the conflict of interests which the directors are subject to if they are allowed to deploy defensive measures can ultimately be resolved by the specific prospect of an attractive severance payment. Furthermore, as Kershaw now argues, the NFR of the City Code may be redundant as even in the absence of the rule, the board could not create and exercise defences without the approval of the shareholders. ${ }^{64} \mathrm{He}$ observes, for example, in relation to whitesquire defences that although it is quite common to grant to the board rolling

\footnotetext{
${ }^{59}$ Kahan/Rock, supra note 9, pp. 871, 893 et seqq.

${ }^{60}$ Ibid, pp. 871, 911.

${ }^{61}$ In this regard Federal Court of Justice (BGH), 27 ZIP (2006), p. 72 - Mannesmann.

${ }^{62}$ No. 4.2 .3 paras. 4 and 5 of the German Corporate Governance Code suggest that the severance payment in case of a premature termination of the management position shall not exceed the value of two years' compensation, and that in case of a change of control it shall not exceed the value of three years' compensation.

${ }^{63}$ Davies/Schuster/de Ghelcke, supra note 17, p. 10.

${ }^{64}$ To this effect especially, see Kershaw, supra note 3, pp. 334 et seqq.
} 
grants of authority to allot shares and rolling waivers of pre-emption rights, the shareholders would most likely refrain from such authorisations granted without limitations if they feared that they would be used for defensive purposes. Thus, a strict NFR would be of much greater practical importance for Delaware companies than UK companies, because it was possible for the board of Delaware companies to create and use a poison pill even without shareholder approval. By contrast for UK companies, however, the NFR is only of clarificatory importance.

At least with regard to the German law it cannot be denied that a strict NFR would have a "constitutive" effect, i.e. that it would prohibit the management board from taking defensive actions which pursuant to general stock corporation law it would be allowed to take. ${ }^{65}$ Recent examples show very clearly that the management board and the supervisory board of a German company which is confronted with a takeover bid are well placed to take such defensive measures, which they would not be able to take if a strict NFR applied. For example, the management board of Hochtief AG, after it had classified the takeover bid of Spanish ACS S.A. as hostile, made use of their authorised capital, with the approval of the supervisory board, by excluding the existing shareholders from their pre-emption right ( $\mathbb{S} 203$ para. 2 sent. 1, 186 para. 3 sent. 4, German Stock Corporation Act), thereby diluting the interest of the offeror from $29.95 \%$ to $27.25 \% .{ }^{66}$ Although this could not prevent the takeover, it still made it more difficult.

Similar conclusions can be reached in relation to other legal systems. For Luxembourg, for example, reference can be made to the takeover of Braas Monier Building Group S.A. by Standard Industries, for Switzerland to the attempted takeover of Sika AG by Compagnie de Saint Gobain; in both cases the board made use of defensive measures. ${ }^{67}$ Such measures are not available under UK regulation, ${ }^{68}$ which even after the experience with the takeover of Cadbury by Kraft held on to the strict NFR and which - by means of the amendments of the City Code adopted in 2011 - only intended to reduce 'the tactical advantage of bidder companies, particularly in hostile deals' and to restore the 'balance in favour of the target'69. Davies/Schuster/de Ghelcke do not only point out that, pursuant to the City Code, the board, if it intends to take defensive measures, needs a post-bid authorisation, while general company law provides for the possibility of pre-bid

65 Denying a "redundancy" of the NFR also, see Davies/Schuster/de Ghelcke, supra note 17, pp. 4 et seqq.; Hopt, Stand der Harmonisierung der europäischen Übernahmerechte Bestandsaufnahme, praktische Erfahrungen und Ausblicke, in Mülbert/Kiem/Wittig, 10 Jahre Wp ÜG (Frankfurt am Main, 2011), pp. 42, 53 et seqq.

${ }^{66}$ In this regard, see Seibt, Übernahmerecht: Update 2010/2011, 5 Corporate Finance Law (2011), pp. 213, 237 et seqq.

${ }^{67}$ See above, note 39.

${ }^{68}$ Davies/Schuster/de Ghelcke, supra note 17, pp. 4 et seqq.

69 Takeover Panel, Response Statement to Review of Certain Aspects of the Regulation of Takeover Bids (2010/22), paras. 2.6 et seq., para 5.1; with regard to the reform cf. Hopt, supra note 65, pp. 60 et seq.; Kershaw, supra note 3, pp. 223 et seqq. 
authorisations. Rather, they also deny that the shareholders would not grant a prebid authorisation, if they were aware that this authorisation would be used to defend against a future takeover bid. In such circumstances the shareholders would be hesitant to trade off the risk of entrenchment against the chance of the offeree making a higher bid due to the bargaining power granted to the board by the defensive powers. ${ }^{70}$

Ultimately, these and similar speculative considerations with regard to rolling grants are not relevant. The decisive factor is that a strict NFR denies the board defensive measures irrespective of the circumstances of the individual case namely, the kind of measure, the motives and intentions of the board and the question of how the measure would have to be assessed pursuant to the respective applicable company law - and that, therefore, a strict NFR - already for reasons of legal certainty, but also for reasons of efficiency - is superior to company law control over defensive measures. ${ }^{71}$

\section{DISCIPLINING IS NECESSARY, BUT MUST BE DONE THE RIGHT WAY - PROPOSALS FOR STRUCTURING THE NFR}

\section{a) NFR as a "Disciplining Tool of Last Resort"}

While in view of the above argument a NFR is not only of clarificatory significance, this does not change the fact that it may generate misguided incentives and therefore has to be scrutinised critically. ${ }^{72}$ Such critical scrutiny has become all the more necessary, because - as was described in the introduction since the adoption of the TBD the legal and economic framework conditions have changed fundamentally. Furthermore, in the UK - in particular as a result of the takeover of Cadbury by Kraft - a view has formed that English companies (which are typically characterised by dispersed ownership and are protected neither by a controlling shareholder nor by the state) have an all too visible "for sale" sign in their front yard. ${ }^{73}$ The scepticism regarding a strict NFR is even more justified considering that the empirical evidence does not tell us whether acquisitions are neither per se beneficial nor per se detrimental; rather, the consequences may only be assessed on a case by case basis and only subsequently. ${ }^{74}$ More than 30 years ago, Coffee showed that takeovers may have varied and even offsetting effects and that too strong a promotion of hostile takeovers may not only increase the probability of inefficient acquisitions, but could also result in an undesirable shift in managerial behaviour and in overdeterrence. He showed that the disciplining function of the markets for corporate control had never been adequately

\footnotetext{
${ }^{70}$ Davies/Schuster/de Ghelcke, supra note 17, pp. 6 et seqq.

${ }^{71} \mathrm{Ibid}$, pp. 5 et seqq.; to this effect, also see Hopt, supra note 65, p. 54.

${ }^{72}$ However, in favour of a strict NFR modelled after the City Code, see Hopt, supra note 16, pp. 69 et seqq. (88); further Armour/Skeele, supra note 7, pp. 1727, 1784 et seqq.; in favour of a shareholder decision, see Davies/Schuster/de Ghelcke, supra note 17, pp. 48 et seqq.

${ }^{73}$ Kershaw, supra note 3, pp. 334 et seqq.

${ }^{74}$ Enriques, supra note 27, pp. 1789, 1791.
} 
scrutinised critically, and - given the mismatch between its theoretical assumptions and the practical reality - was likely only to serve as a remedy of last resort for massive managerial failures and not as the principal enforcer of corporate accountability. ${ }^{75}$ Wymeersch's views go in the same direction. He emphasises that an entrenchment of incumbent board members and block members may be detrimental to the interest of the company or all shareholders, but he also regards the (unsolicited) takeover bid as only a disciplining instrument of last resort and recommends that other disciplining instruments be used, such as shareholder activism, and recommends allowing the board not only the search for a white knight, but enabling to use any measure 'that is likely to improve the financial condition of the shareholders'. He emphasises that the prevention of an entrenchment by the incumbent board should not be an end in itself of any regulation and, therefore, in particular should not be prohibited to the detriment of the shareholders. ${ }^{76}$

\section{b) Activating the Shareholders?}

Considering the fact that a disciplining of the management is particularly necessary in companies with a dispersed ownership, but not in companies with a controlling or at least influential shareholder, ${ }^{77}$ dispersed shareholders need to be activated to fulfil the function of the NFR in order to discipline the directors, without triggering the misguided incentives generated by the NFR.78 However, implementing this idea faces considerable difficulties.

aa) First, the question arises whether the shareholders of a company with dispersed ownership have the required instruments at their disposal to exercise opposing power in the takeover situation. This question cannot be answered easily one way or the other. Without doubt, it can be determined also for the large public companies that activist shareholders approach the board to articulate their views on the further development of the company and to criticise any developments they do not approve of. Occasionally, activist shareholders - acting from a clear minority position - even succeed in bringing about amendments in the composition of the supervisory board. One example in this regard is the course of action taken by Acitve Ownership Capital with regard to Stada $A G .{ }^{79}$ On the basis of an interest of $6.98 \%(1.92 \%$ thereof in derivatives) and with the support of Guy Wyser-Pratte (who held an interest of less than 3\%), Active Ownership Capital managed to have the chairman of the supervisory board dismissed in the general meeting of shareholders of 26 August 2016, after proxy advisor ISS had recommended to support this proposal. In addition to activist shareholders,

${ }^{75}$ Coffee, supra note 9, pp. 1148 et seqq.

${ }^{76}$ Wymeersch, supra note 30, pp. 1390 et seqq. (1395).

77 See above III. 1. a.

${ }^{78}$ To this effect also Wymeersch, surpa note 29, pp. 1390 et seqq.

79 In more detail on the following, Seibt, Handlungsoptionen gegen Aktivisten, Börsen-Zeitung 170/2016 (3 September 2016), p. 13; Graßl/Nikoleyczik, supra note 31, p. 52. 
associations promoting shareholder interests are playing an increasingly more important role; examples in this regard include the special audits at Deutsche Bank $A G$ and ThyssenKrupp $A G$, which in each case were initiated at the instigation of Deutsche Schutivereinigung für Wertpapierbesitz e.V. (German Investor Protection Association). In a public company with a one-tier governance system, powerful rights for the dismissal of directors may also play a role. In any case, it cannot be argued against their disciplining effect that the assertion of the dismissal right generally comes too late to prevent the frustration of a takeover bid. ${ }^{80}$ The relevant consideration is whether the board members feel exposed to a real risk of being held responsible in the event of the frustration of a takeover bid that is viewed as being beneficial by the shareholders.

With regard to German law, there has been a corresponding general discussion for a long time in connection with the question whether the competences of the shareholders regarding the assertion of claims for damages of the company against members of corporate bodies acting in breach of duty should be extended and whether the shareholders should be granted stronger incentives for exercising their powers, e.g. in the form of a share of their own in the damages obtained by means of a dispute. ${ }^{81}$ With regard to the frustration of a takeover bid which is relevant here, an action of the shareholder in its own right could be considered - which, depending on the situation in the individual case, could result in a cease-and-desist order, removal or damages. On the basis of $\int 33$ of the WpÜG, such an action, in my view rightly, is supported now by some authors in those cases where the management board takes defensive measures. ${ }^{82}$ The underlying rationale that in this case that the management board's actions infringe the (residual) competence of the general meeting of shareholders to decide on defensive measures could also be transferred to other jurisdictions. With this, the shareholders would indeed have a potent instrument in their hands, with which they could discipline the board and prevent it from defending against a takeover bid which the shareholders view positively.

$\mathrm{bb})$ The Directive on amending the SRD mentioned above ${ }^{83}$ acknowledges an important role of institutional investors and fund managers in the corporate governance of listed companies. However, recital no. 9 of the Draft Directive also states:

However, the experience of the last years has shown that institutional investors and asset managers often do not engage with companies in which they hold shares and evidence shows that capital markets often exert pressure on companies to perform in the short term, which may jeopardise the longterm financial and non-financial performance of companies and lead, among

\footnotetext{
80 To this effect, however, Davies/Schuster/de Ghelcke, supra note 17, p. 12.

${ }^{81}$ In more detail, Habersack, supra note 42, pp. E 96 et seqq.

${ }^{82}$ Emmerich/Habersack, supra note 35, p. 146.

${ }^{83}$ See supra note 31.
} 
other consequences, to a suboptimal level of investments, for example in research and development to the detriment of the long-term performance of both the companies and the investor.

It remains to be seen whether the measures provided for in the Directive for increasing the transparency of the investment conduct of institutional investors, fund managers and proxy advisors (which the institutional investors and fund managers are using in many cases) will be sufficient to create a closer link between the investment interests and the company's interest in a sustainable development. As long as no progress is discernible in this respect, one will hardly be able to rely on institutional investors and fund managers in the endeavour to discipline the directors. Furthermore, the current behaviour of institutions and their fund managers raises real concerns about the operation and effects of the NFR in practice.

In this regard, the effects of shareholder behaviour on bids were identified by the previous chairman of Cadbury, Roger Carr. He focused in particular on the willingness of long funds to sell to short term merger arbs following the announcement of the deal and the bias this generated in favour of the bidder. One of his recommended responses was to increase the acceptance quota required for a successful takeover bid, which under the City Code currently amounts to 50\%.84 In the alternative, he recommended disregarding the shares held by short term shareholder (shareholders who purchase following the announcement of the offer) in the determination of whether the acceptance quota has been achieved. 85 However, both proposals are highly problematic. Increasing the acceptance quota to more than $50 \%$ would not only significantly restrict contestability, but would also result in subsequent problems regarding the MBR; namely, it would then be possible that while the takeover bid is unsuccessful, the bidder is nonetheless obliged to make a mandatory bid. ${ }^{86}$ The proposal to disregard the shares held by short term investors in the determination of the acceptance quota would generate several legal (equal treatment) and practical (in which manner would the shares be determined that are not to be considered) problems and, ultimately, would fail to address the root of the problem (that long term investors, who consider the bid to be below fundamental value, are willing to sell their shares through the market after publication of the takeover bid) .87

\footnotetext{
${ }^{84}$ In this regard, see also below IV. 5.

${ }^{85}$ Carr, speech at Said Business School, 9 February 2010, available at: http://podcasts.ox.ac. uk/roger-carr-cadbury-hostile-bids-and-takeovers.

${ }^{86}$ Approving of the proposal, however, Kershaw, supra note 3, pp. 355 et seqq., 369, who seeks to solve the problem specified in the text by the Panel imposing on the bidder to reduce its interest to under $30 \%$

${ }^{87}$ Rejected also by Kershaw, supra note 3, pp. 361 et seqq.
} 


\section{c) Shareholder Autonomy}

The above observations show that all approach to the disciplining of directors involves several theoretical and practical limitations. A strict NFR may set misguided incentives and should therefore be considered only as a "disciplining tool of last resort". But activating the shareholders does not necessarily promise more effective accountability. If this is correct then it is essential that we enable the shareholders to decide for themselves as to whether or not the NFR shall apply to their company.

First, let us consider Davies/Schuster/de Ghelcke's proposal according to which the strict NFR under Art. 9 of the TBD is applied, unless the general meeting of shareholders resolves that the NFR shall not apply. 88 Thus, the member states' option right under Art. 12 of the TBD would be abolished and it would be in the sole discretion of the respective company to decide about the application of the NFR. This appears convincing, not least in view of the fact that Davies/Schuster/de Ghelcke were able to prove that with the adoption of the TBD a significant shift away from bidder friendliness occurred. ${ }^{89}$ If one further considers that pursuant to Art. 12 para. 2 of the TBD in cases where a member state opts out of the application of the NFR it is up to the shareholders to reintroduce the NFR by resolution with a majority sufficient to amend the company's articles, it is not surprising that such an opt-in is irrelevant in practice. ${ }^{90}$ If the member states' option right were to be abolished and the application of the NFR thus to become the default rule, this would still be a flexible system; however, it would be up solely to the shareholders to provide for an opt out by way of a general meeting resolution.

The proposal of Enriques/Gilson/Paccess is similar. ${ }^{91}$ Based on the consideration that takeovers are neither per se good nor per se bad, but that, rather, the success of a takeover is dependent on a variety of individual factors, they argue that takeover regulation should neither impede nor promote takeovers. They argue in favour of an "unbiased" and, thus, largely abrogable takeover law. The articles of association should not only set forth provisions about the NFR and the MBR, but it should also be possible to provide that decisions on the acceptance of the bid are not made individually, but by resolution of the general meeting of shareholders. These quite extensive proposals cannot be considered in detail here. ${ }^{92}$ But especially the proposal to transform Art. 9 of the TBD into a

\footnotetext{
${ }^{88}$ Davies/Schuster/de Ghelcke, supra note 17, pp. 48 et seqq. (54); supporting Hopt, supra note 65, pp. 55 et seqq.; sceptical Wymeersch, supra note 30, p. 1394.

${ }^{89}$ Davies/Schuster/de Ghelcke, supra note 17, p. 52 table 4.

${ }^{90}$ Davies/Schuster/de Ghelcke, supra note 17, p. 41.

${ }^{91}$ Enriques/Gilson/Pacces, The Case for an Unbiased Takeover Law (with an Application to the European Union), 4 Harvard Business Law Review (2014), pp. 85 et seqq.; see further Enriques, supra note 27, pp. 1789 et seqq.

92 Critically Hopt, supra note 16, pp. 26 et seqq.; Fedderke/Ventoruzzo, The Biases of an "Unbiased" Optional Takeovers Regime: The Mandatory Bid Threshold as a Reverse Drawbridge, ECGI Law Working Paper N. 304/2016, pp. 12 et seqq. With regard to the MBR, see below IV. 4.
} 
genuine default rule and to give (only) the general meeting of shareholders the right to opt out, is along the same line as the proposal of Davies/Schuster/de Ghelcke and as the latter is convincing. However, in order to avoid the once resolved opt out being "cemented" and, thus, de facto making the non-application of the NFR the default rule, it should always only be possible to provide that the opt out will only apply for a limited period. ${ }^{93}$

\section{PRE-BID DEFENCES}

Pursuant to Art. 9 para. 2 sub-para. 2 sent. 1 of the TBD, the NFR only applies from the moment in which the board of the offeree company receives the information referred to in the first sentence of Art. 6 para. 1 of the TBD, i.e. from the decision on the issuing of a takeover bid. However, pursuant to Art. 9 para. 2 sub-para. 2 sent. 2 of the TBD, the member states may stipulate that the NFR applies already from an earlier point in time, for example, as provided by Rule 21.1 of the Takeover Code as soon as the board of the offeree company becomes aware that the bid is "imminent". Pursuant to this rule where a defensive nonordinary course action is not completed at the point in time when the bid is deemed to be "imminent", the action becomes subject to the non-frustration prohibition even when the target is contractually bound to complete the action. ${ }^{94}$ This bidder-friendly regulation (which is further reinforced by an application by the Panel that is also bidder-friendly $)^{95}$ is supplemented by rules on possible offer announcements which are primarily intended to prevent the "siege" of the offeree company. ${ }^{96}$ Accordingly, under the "put up or shut up" rule already mentioned above (Rule 2.6, City Code), the offeree company can be forced to announce whether or not it intends to make a takeover bid. If it announces it does not intend to do so then it is prohibited from making such a bid for the next six months.

By way of contrast, in Germany $\int 33$ of the WpÜG not only permits the management board to take extensive defensive measures, but it only becomes applicable in the first place once the bidder has published its intention to make a takeover bid. Experience shows that this provision is imperfect. ${ }^{97}$ This becomes particularly clear when we consider the example of the failed takeover of Kali+Salz.

\footnotetext{
${ }^{93}$ Davies/Schuster/de Ghelcke, supra note 17, p. 55: five years.

${ }^{94}$ In more detail Kershaw, supra note 3, pp. 323 et seqq.

95 Cf. the reference to a Panel announcement in Kershaw, supra note 3, p. 323 (fn. 7).

${ }^{96}$ Kershaw, supra note 3, pp. 155 et seqq.; Hopt, supra note 16, pp. 106 et seqq.

${ }_{97}$ To this effect see also Seibt, Verhaltenspflichten und Handlungsoptionen der Leitungs- und Aufsichtsorgane in Übernahmesituationen, in Mülbert/Kiem/Wittig, supra note 65, pp. 148, 153 et seqq.
} 
$A G$ by Potash. 28 The opposition articulated by the offeree company and in politics was so vehement that a takeover bid was not even made. The management board of Kali+Salz $A G$ did not have to observe any restrictions under takeover law, since \33 of the WpÜG could not yet apply. The example shows that the German legislator would be well advised to also use the regulatory option in Art. 9 para. 2 sub-para. 2 sent. 2 of the TBD and extend the scope of application of the NFR to "imminent offers".

\section{RESULT}

While it is evident that board members have to be disciplined and especially in takeover situations, it is difficult to determine which approach to the discipline is optimal. A strict NFR modelled after that of the City Code may result in misguided incentives and is suitable at most as a disciplining tool of last resort. The obvious substitute of relying on the increasing shareholder activism and of trusting that the shareholders will be able to discipline the board also in a company with dispersed ownership is compelling in principle; however, since the active shareholders often seek a short-term maximisation of returns, misaligned incentives cannot be avoided in this context, either. In view of these findings, it is submitted that more emphasis should be placed on the decision by the shareholders, and that the member states' option right under Art. 9 para. 2 of the TBD be abolished and (only) the shareholders should be given the possibility to opt out of the strict NFR - which would continue to serve as the default rule. Such an opt out should only be possible for a limited period of time.

\section{MBR - AN INDISPENSABLE INSTRUMENT FOR THE PROTECTION OF MINORITY SHAREHOLDERS?}

\section{STARTING POINT}

\section{a) Origin and Concept of the European MBR}

As we observed in the introduction, although in the run up to the Directive the MBR was vehemently criticised, in the end it was included in the TBD without great difficulty. Even in retrospect, this is indeed surprising. This is because while the MBR has been a fixture and a generally accepted part of the City Code since 1972 and, therefore, from a UK perspective a corresponding European provision appeared entirely natural, the situation was and is different from the German perspective especially when one considers the fact that the German Stock

\footnotetext{
${ }^{98}$ In more detail Gaul, Politische Einflussnahme bei der gescheiterten Übernahme von $\mathrm{K}+\mathrm{S}$ durch Potash- Effektives Verteidigungsmittel oder unzulässiger Protektionismus?, $61 A G$ (2016), pp. 484 et seqq.
} 
Corporation Act in $\iint 291$ et seqq., 311 et seqq. contains detailed provisions intended to ensure the protection of the outside shareholders of a controlled company. This was one of the reasons why the TBD draft presented in 1996 contained a provision intended to allow the member states to replace the MBR by 'other appropriate and at least equivalent means' in order to protect the minority shareholders. ${ }^{99}$ This provision was aimed, in particular, at provisions under the law on groups of companies along the lines of those of the German Stock Corporation Act. There were a number of reasons for the German legislator eventually relinquished its opposition ${ }^{100}$ to a binding MBR. Alongside the experience of the Mannesmann takeover (which was based on a voluntary bid) and the fact that Art. 5 of the TBD left significant implementation discretion to the national legislator, it was also the concern that the 'equivalent regulation clause' might result in the TBD 'superimposing' the provisions under the law on groups of companies. ${ }^{101}$ As a consequence, provided that the controlling shareholder is in a position to exert controlling influence over the company and, thus, a dependency relationship as defined in $\ 17$ of the German Stock Corporation Act exists, ${ }^{102}$ the shareholders of a listed company with a controlling shareholder are now protected not only by the provisions in $\int \mathbb{S} 291$ et seqq., 311 et seqq. of the German Stock Corporation Act, but also by the MBR. This is important not least for the reason that under the German Stock Corporation Act the outside shareholders of a dependent company have no tendering right as long as the dependent company has not concluded a control or profit and loss transfer agreement. In contrast, due to the MBR the outside shareholders benefit from a mandatory acquisition offer, which pursuant to Art. 5 para. 4 of the TBD has to be equivalent to at least the prices paid in any prior and subsequent acquisitions and, thus, enables them to participate in any control premium.

\section{b) American "Market Rule" as an Alternative Concept}

Not only with regard to the NFR, but also with regard to the MBR, the City Code and the TBD deviate fundamentally from US law, which refers the question of a mandatory bid to company law and, thus, to the law of the individual states. In

99 OJ 1996, C 162/5; in more detail in this regard, Hopt, Europäisches und deutsches Übernahmerecht, 161 ZHR (1997), pp. 368, 384 et seqq.; Krause, Der revidierte Vorschlag einer Takeover-Richtlinie $51 A G$ (1996), pp. 209, 211 et seqq.

100 From the critics cf. in particular Altmeppen, Neutralitätspflicht und Pflichtangebot nach dem neuen Übernahmerecht, 22 ZIP (2001) pp. 1073, 1082 et seqq.; Assmann, supra note 4, p. 570; Hommelhoff/Kleindiek, Takeover-Richtlinie und europäisches Konzernrecht, $35 A G$ (1990) pp. 106 et seqq.

${ }^{101}$ Habersack/Mayer, Der neue Vorschlag 1997 einer Takeover-Richtlinie - Überlegungen zur Umsetzung in das nationale Recht, 18 ZIP (1997), pp. 2141 et seqq.; see also Hopt, supra note 99, pp. 368, 387 et seqq.

102 Regarding the differences between control as defined in $\iint 29$ para. 2, 35 of the WpÜG and dependency as defined in $\iint 17,311$ et seqq. of the German Stock Corporation Act see Emmerich/Habersack, supra note 35, p. 43; Habersack, supra note 13, p. 622. 
fact, only two states have a regime comparable to the MBR, namely Pennsylvania and Maine. ${ }^{103}$ In contrast, the other states and, thus, in particular also Delaware, follow the "market rule" and, therefore, in principle reject a participation of the outside shareholders in a possible control premium - be it as a result of the bidder submitting an acquisition offer to the outside shareholders, or as a result of the seller passing on part of the control premium received by it. While exceptions from the market rule are derived from the fiduciary duties of the controlling shareholder, their practical significance is limited. ${ }^{104}$ This applies, for example, with regard to the obligation of the current controlling shareholder to share a control premium if it can be clearly envisaged that the acquirer of the controlling interest will misappropriate ("loot") the assets of the target company. 105 In contrast, apart from such scenarios, U.S. takeover and company law relies on the outside shareholders being awarded sufficient protection by general company law after a change of control. In contrast, the Commission endeavours to extend the MBR and, in particular, to prohibit the practice of low balling (for example, by additional threshold values for mandatory bids or minimum requirements for the acceptance of takeover bids), even though the outside shareholders of a controlled company will be protected in the future against an exploitation of the controlled company by provisions on related party transactions and, in addition, active shareholders, when present, will keep the controlling shareholders in check.

2. The Allocation OF THE CONTROL PREMIUM - A QUESTION OF LAW, NOT ECONOMY

In view of the fact that U.S. law and the City Code answer the question whether the outside shareholders should participate in the control premium in a diametrically opposed manner, it is not surprising that no agreement exists with regard to the economic assessment of the MBR, either. The MBR's opponents assert that the MBR makes desirable takeovers more expensive and may even prevent mergers. In addition, it may have the effect of promoting concentration, by granting the outside shareholders the possibility of tendering their shares to the controlling shareholder. ${ }^{106}$ In contrast, those supporting the MBR argue that the rule prevents inefficient acquisitions - in particular those that are likely to result in the looting of the target company. They object to the assumption that the MBR had the effect of promoting concentration by pointing out that the capital invested

\footnotetext{
103 Hopt, supra note 16, pp. 33 et seqq.; Schuster, The Mandatory Bid Rule: Efficient, After All?, 76 The Modern Law Review (2013), pp. 529, 535 et seqq.

104 Schuster, supra note 103, pp. 529, 537 et seqq.

105 In more detail, see Elhauge, The Triggering Function of Sale of Control Doctrine, 59 The University of Chicago Law Review (1992), pp. 1465, 1503 et seqq.

106 Easterbrook/Fischel, Corporate Control Transactions, 91 Yale Law Journal (1981/82), pp. 698 et seqq.; Romano, The Political Economy of Takeover Statutes, 73 Yale Law Review (1987), pp. 111 et seqq.; Wymeersch, Übernahmeangebot und Pflichtangebote, 31 ZGR (2002), pp. 520,542 et seqq.
} 
in the target company could not be used otherwise. ${ }^{107}$ Indeed, any generalisation should be avoided and it should be conceded that the success of any takeover and, thus, also the consequences of the MBR - can only be assessed on a case by case basis. ${ }^{108}$

The notion - which goes back to Berle/Means - that control was a "corporate asset" and, therefore, all shareholders had to participate in a control transaction, 109 is economically plausible subject to the argument that the controlling shareholder has Private Benefits of Control ("PBC") and is in a position to use control to its pecuniary and non-pecuniary advantage. However, it is also economically plausible that the increase of the cost of the acquisition of control has detrimental effect of the efficient operation of the market for corporate control and therefore should be prevented by way of the acquirer of control excluding the outside shareholders ("nonpayers") from the benefits of the takeover. ${ }^{110}$

The assumption that control was a "corporate asset" is based on the presumption that the controlling shareholder has the capability to exploit the controlled company. However, this presumption, in particular, does not apply if and to the extent that the law applicable to the controlled company seeks to prohibit inappropriate transactions between the company and the controlling shareholder, either generally by means of fiduciary duties or by specific provisions governing related party transactions. ${ }^{111}$ Certainly, the controlling shareholder may benefit not only from movements of assets, but also very generally from synergy effects and comparable PBCs. ${ }^{112}$ However, it is an open question both in economic and in legal respects whether external shareholders should be entitled to expect to participate specifically in these benefits. If one considers that the generation of synergy effects is based in any case also, if not decisively, on circumstances attributable to the sphere of the controlling shareholder, the notion that in the case of a participation the outside shareholders would be granted a windfall gain appears by no means inappropriate.

\footnotetext{
107 Hopt, supra note 16, pp. 33 et seqq.; Schuster, supra note 103, pp. 529, 539 et seqq.; Reul, Die Pflicht zur Gleichbebandlung der Aktionäre bei privaten Kontrolltransaktionen, 1991, pp. 191 et seqq., 238 et seqq.; Krause, Zur Gleichbehandlung der Aktionäre bei Übernahmeangeboten und Beteiligungserwerb (Teil I und II), 50 Wertpapier-Mitteilungen (WM) (1996), pp. 845 et seqq., 893 et seqq.

${ }^{108}$ Enriques, supra note 27, pp. 1789, 1791.

${ }_{109}$ Berle and Means, The Modern Corporation and Private Property, 1932 (1968), pp. 215 et seqq.; rejecting e.g. Easterbrook/Fischel, supra note 106, pp. 698, 715 et seqq.

110 Grossmann/Hart, supra note 40, pp. 42, 59.

111 See already Habersack/Tröger, supra note 40, p. 1, 2; also Wymeersch, supra note 30, pp. 1384 et seqq.

112 In more detail, Dyck/Zingales, Private Benefits of Control: An International Comparison, 59 The Journal of Finance (2004), pp. 537 et seqq.; see further Schuster, supra note 103, pp. 539 et seqq.
} 


\section{JUSTIFYING A STRICT MBR?}

The above findings lead directly to the question of the legitimation of a strict, i.e. non-optional, MBR under company law.

\section{a) Appropriateness of Preventive Protection?}

In the event that the target company comes under the control of a shareholder for the first time or that a change of control occurs, the MBR enables the outside shareholders to sell their shares at a price meeting at least the requirements of Art. 5 para. 2 of the TBD. It thus reacts to the mere risk that the controlling shareholder may exert his influence on the company to the latter's detriment, but not to an actual adverse effect on the interests of the target company and its outside shareholders. ${ }^{113}$ This preventive protection is granted by the MBR not only in the event that the company comes under the control of a shareholder for the first time, but also in the event of a change of control. Irrespective of whether functionally one considers the MBR to be part of capital markets law or of company law, 114 it thus supplements the regular mechanisms of company law for preventing an exploitation of the target company.

Obviously, the MBR is no substitute for an ex post protection of the shareholders who did not leave the controlled company. ${ }^{115}$ However, the decisive question is whether internal control mechanisms are capable of ensuring a sufficient and appropriate protection of the outside shareholders and therefore an additional protection by the market for control over enterprises is not necessary. One could be inclined to respond to this question simply by pointing out that general company law and the law on groups of companies do not provide for a right of the outside shareholders to leave the company that has come under another party's control. ${ }^{116}$ However, this would mean to take too narrow a view, since the very question to be answered is whether, in view of the ex postprotection provided for in general company and the law on groups of companies,

\footnotetext{
113 Correctly emphasised by Davies, The Notion of Equality in European Takeover Regulation, in Payne/Prentice, Takeovers in English and German Law (2002), p. 25; Kershaw, supra note 3, pp. 249 et seqq.; Hopt, supra note 16, p. 39.

114 This question was intensively discussed for German law and answered by Federal Court of Justice in favour of an allocation to capital markets law, cf. German Federal Court of Justice, judgment of 11 June 2013 - II ZR 80/12 16 NZG 2013 p. 939 para. 19; for US law see above 1. b.

115 Hopt, supra note 16, p. 39; apparently different Schuster, supra note 103, p. 534: 'substitute for, or an add-on to, other minority protection devices.'

116 \ 305 of the German Stock Corporation Act provides for a right of withdrawal of the outside shareholders only in the event a control or profit and loss transfer agreement is concluded; in contrast, in the case of mere dependency as well as in groups not based on agreements - and, thus, in cases in which the MBR generally applies. $\iint 311$ et seqq. of German Stock Corporation Act are limited to the obligation to prepare a report on intra-group exchange relationships and to having this report examined by the supervisory board and the auditor, as well as the prohibition of influencing the dependent company in a detrimental manner and without compensation; in more detail Emmerich/Habersack, supra note 35, p. 477.
} 
the MBR is excessive. Taking into account the changes in the MBR's legal environment already mentioned above, it is clear that company law provides adequate protection. ${ }^{117}$ In particular, the provisions of the SRD on related party transactions and measures for the improvement of corporate governance coupled with the emergence of active shareholders today provide for the protection of the outside shareholders which did not exist to this extent at the time the Directive was enacted. This story of increased shareholder protection following the adoption of the MBR can be told in the United Kingdom as well as in Germany.

\section{b) Equal Treatment of Shareholders?}

The MBR cannot simply be legitimised by the principle of equal treatment of shareholders. That control is a "corporate asset" belonging to all shareholders is only plausible, at all, where there is a controlling shareholder with significant PBCs. ${ }^{118}$ However, this is not the case to the extent that provisions under company law and the law on groups of companies prevent the exploitation of the controlled company by the controlling shareholder. In contrast, outside shareholders benefit from PBCs resulting from synergy effects without any contribution on their part. Consequently, from the perspective of equal treatment, this means that there is no unequal treatment in the first place, if the seller of a block of shares conveying control or material influence receives a price premium and shareholders who only hold an infinitesimal percentage of shares do not participate therein. On the contrary, it would constitute unequal treatment if the small shareholders could demand to be put in the same position as the seller of a block of shares. ${ }^{119}$ In contrast, where the offeror obtains control over a company which so far was not controlled, this is typically based on a voluntary takeover bid; pursuant to Art. 5 para. 2 of the TBD, no mandatory bid is necessary in these cases, as the shareholders have had the opportunity to accept the voluntary bid. However, where control over a company that so far was not controlled has not been acquired by way of a voluntary takeover bid, but in another manner, the offeror will usually not have paid a control premium, either. Since the outside shareholders had not received an offer from the new controlling shareholder, they now find themselves for the first time in the role of the shareholder of a controlled company. They then bear the risk associated with whether the instruments of company law will actually be capable of preventing an exploitation of the company by the controlling shareholder and of whether the envisaged synergy effects will actually be realised. This risk as well as the narrowing of the market resulting from the acquisition of control may in turn lead to a fall in stock prices. Therefore, upon closer examination a mandatory bid is justified solely in

117 To this effect also Kershaw, supra note 3, pp. 249 et seqq.; Wymeersch, supra note 30, pp. 1385 et seqq.; contrary opinion, see Hopt, supra note 16, pp. 39 et seqq.

${ }^{118}$ Cf. in this respect below 2.

${ }^{119}$ To this effect also Kershaw, supra note 3, pp. 251 et seqq. 
the - very atypical - case that the offeror obtains control over a company that was not obtained by means of a voluntary takeover bid, but in another manner, and where corporate law is incapable of protection the shareholders going forward. ${ }^{120}$

\section{FIRST CONCLUSIONS}

\section{a) MBR as a Default Rule?}

In view of these findings, it appears worth considering whether Art. 5 TBD should be a mere default rule. This would allow the companies - more specifically: the shareholders - the right to abrogate the MBR by way of a decision of the general meeting of shareholders. This proposal is not new. Such an optional MBR has been favoured, as was already mentioned in connection with the NFR, in particular by Enriques/Gilson/Paccess, ${ }^{121}$ and recently Kershaw endorsed their view. ${ }^{122}$ In contrast, Hopt and Fedderke/Ventoruzzi, in particular, reject the proposal, ${ }^{123}$ with the proviso that the latter authors at least concede that the MBR can be inefficient and is 'far from being a flawless regulatory approach'. Instead of the option right, they favour extending the exception in Art. 5 para. 2 of the TBD to apply already in the case of a partial bid. ${ }^{124}$ Outside of the EU ${ }^{125}$, an optional MBR can be found, in particular, in Swiss law; Art. 22, 32 of the BEHG (Swiss Stock Exchange Act) which allows not only an increase of the control threshold from $331 / 3 \%$ to up to $49 \%$, but also provides for an opt out. ${ }^{126}$

The argument that the mandatory MBR reduces transaction costs by saving market actors the trouble of inspecting the articles of association of individual companies is weak. ${ }^{127}$ Even irrespective of the fact that the currently applicable version of Art. 5 of the TBD already grants the national law significant legislative scope of discretion, access for the investors and intermediaries to the relevant information does not present a problem. ${ }^{128}$ Besides, in the context of their corporate governance companies are specifically requested to design custom solutions and to subject these to a market test by means of the comply-or-explain

\footnotetext{
${ }^{120}$ Kershaw, supra note 3, pp. 194 et seqq., 251 et seqq.

121 Enriques/Gilson/Pacces, supra note 93, pp. 85, 90 et seqq.; see further Enriques, supra note 27, pp. 1789 et seqq.

122 Kershaw, supra note 3, pp. 255 et seqq.

${ }^{123}$ Hopt, supra note 16, pp. 43 et seqq.; Fedderke/Ventoruzzo, The Bias of an "Unbiased" Optional Takeovers Regime: The Mandatory Bid Threshold as a Reverse Drawbridge, ECGI Law Working Paper No. 304/2016, pp. 12 et seqq.

${ }^{124}$ Fedderke/Venoruzzo, supra note 123, pp. 29 et seqq.

125 Regarding the liberalisation of the MBR under Italian law that occurred in 2014, see Fedderke/Ventoruzzo, supra note 123, pp. 7 et seqq.

126 See the example of Sika AG in German Federal Administrative Court, judgement of 27 August 2015 - B-3119/2015; further Hopt, supra note 16, pp. 43 et seqq.

${ }_{127}$ To this effect, however, Hopt, supra note 16, p. 45.

128 Enriques/Gatti, Creeping Acquisitions in Europe: Enabling Companies to Be Better Safe than Sorry, ECGI Law working paper N. 264/2014, pp. 54 et seqq.
} 
mechanism. ${ }^{129}$ An option right of the individual companies in respect of the MBR would be fully in line with this.

Neither can it be argued that typically a controlling shareholder had no interest in opting out, because otherwise the takeover of the company by an offeror who acquires the shares that are in free float would be made easier. In fact, it is rather likely that also the controlling shareholder would benefit from the possibility of achieving a change of control without the necessity of a mandatory bid. ${ }^{130}$ As far as companies held in free float are concerned, it is up to the shareholders to consider the advantages and disadvantages of opting out. As was already shown with regard to the NFR, an opting out should, in any case, always only be possible for a limited period of time. ${ }^{131}$

As long as Art. 5 of the TBD provides for a stringent MBR, national law could at least delegate the determination of the control threshold to the articles of association and thus enable the shareholders to make takeovers more difficult by choosing a particularly low control threshold and to facilitate takeovers by choosing a rather high control threshold. This would indeed be permissible under Art. 5 of the TBD, ${ }^{132}$ and Italian law now actually provides for such a possibility, at least for small and medium companies. ${ }^{133}$ It would also be permissible for the national law of the member states - already under the currently applicable version of Art. 5 of the TBD - to provide for staggered control thresholds and to stipulate, for example, that in the case of an acquisition of $50 \%$ of the voting rights a stringent, i.e. non-optional MBR is to apply, while in the case of an acquisition of $30 \%$ to $49,9 \%$ an opting out is possible. ${ }^{134}$

\section{b) Extension to Multilateral and Organised Trading Facilities as Well as to Contracts for Difference}

In other respects, the TBD - and with it the MBR - should be made more stringent, namely by extension of its scope of application. First, it is not convincing that only such companies fall within the scope whose shares are traded in the regulated market; rather, it would be consistent to adjust the scope of application of the TBD to that of the Market Abuse Regulation (MAR) and, thus,

\footnotetext{
${ }^{129}$ See above III. 1. b.

${ }^{130}$ Cf. the example of the intended takeover of Sika AG, in this respect see supra note 39.

131 See above III. 4. c.

132 This would not constitute a defensive measure as defined in the NFR, already for the reason that it is not the board, but the general meeting of shareholders who decides about the amount of the control threshold; contrary view apparently Fedderke/Ventoruzzo, supra note 123, pp. 10 et seqq.

133 In more detail Fedderke/Ventoruzzo, supra note 123, pp. 9 et seqq.

134 To this effect, see the proposal of Kershaw, supra note 3, p. 258.
} 
also to include those companies whose shares are traded in a multilateral or organised trading facility as defined in Art. 2 para. 1 lit. b(c) of the MAR. ${ }^{135}$

In addition, for the purpose of determining the control threshold, "interests in shares" and, thus, in particular contracts for difference should also be taken into account - as is the case in Rule 9.1 of the City Code. ${ }^{136}$ The discussion of creeping acquisitions has shown that notification thresholds relating to voting rights can easily be circumvented by cash-settled derivatives. ${ }^{137}$ The resulting extension of Arts. 13, 13a of the Transparency Directive to cash-settled derivatives should serve as a model also for the MBR. ${ }^{138}$

\section{LOW-BALLING}

By way of introduction, it was already shown that the Commission intends to take measures in order to prevent the MBR from being circumvented by the acquisition of interests 'close to the mandatory bid threshold' and the subsequent launching of a mandatory bid 'for a low price'139. The scenarios by which the Commission is guided in this respect are generally known and in many cases relate to German law, the MBR of which - $\int \S 35,29$ para. 2 of the WpÜG - is triggered by the acquisition of $30 \%$ or more of the voting rights of the offeree company (provided that the acquisition is not based on a voluntary takeover bid) and does not provide for an additional threshold. These scenarios include, for example, the voluntary takeover bid made by Spanish $A C S S . A$. for the shares of Hocbtief $A G$, after it held already almost $30 \%$ of the Hocbtief shares, ${ }^{140}$ the mandatory bid issued by Porsche Automobilholding SE after the acquisition of a controlling interest in Volkswagen $A G^{141}$ as well as the mandatory bid of Volkswagen $A G$ in respect of $M A N$ SE. In these and other cases the offer was deliberately made at an unattractive price (which was in compliance with the minimum price provisions), with the consequence that it was accepted only by a small number of shareholders. Afterwards, the bidder was in each case able to further increase its interest,

\footnotetext{
135 For an inclusion of OTC trading, see Wymeersch, supra note 30, pp. 1375 et seqq.; see further Merkt, Das übernahmerechtliche Pflichtangebot im Spiegel der Reformdiskussion, in Veil, Übernahmerecht in Praxis und Wissenschaft, 2009, pp. 53, 60.

${ }^{136}$ In more detail on Rule 9.1 City Code, see Kershaw, supra note 3, pp. 237 et seqq.

${ }^{137}$ Enriques/Gatti, supra note 128, pp. 24 et seqq.; Habersack, Beteiligungstransparenz adieu? Lehren aus dem Fall Continental/Schaeffler, 53 AG (2008), pp. 817 et seqq.

138 In favour of an optional approach also in this respect - with deliberations worth considering - see Enriques/Gatti, supra note 128, pp. 30 et seqq., 50 et seqq.

${ }^{139}$ European Commission, supra note 19, paras. 21 et seqq.

${ }^{140}$ In this regard, Assessment Report, supra note 18, pp. 127 et seqq.; Baums, Low Balling, Creeping in und deutsches Übernahmerecht, 31 ZIP (2010), pp. 2374, 2375; von Bülow, 10 Jahre WpÜG - eine kritische Bestandsaufnahme, in Mülbert/Kiem/Wittig, supra note 65, pp. 9, 31 et seqq.; Cascante, "12 Years a Rave" - Schlüsseltransaktionen im deutschen Übernahmerecht von 2002 bis 2013, in: Festschrift für Wegen (Munich 2015), pp. 175, 188 et seqq.

${ }^{141}$ In this regard, von Bülow, supra note 140, pp. 9, 27 et seqq.; Cascante, supra note 140, p. 183.
} 
without being forced to issue a new mandatory bid or to make a subsequent payment to the shareholders who had accepted the offer of the balance between the offer price and the price paid in the course of the subsequent acquisition.

The low-balling was occasionally accompanied by a creeping-in, i.e. a secret building-up of a stake on the basis of contracts for difference. ${ }^{142}$ While this form of building-up of a stake is now, as was mentioned, covered by the Transparency Directive, it is not covered by the TBD. However, even if the MBR were to extend to contracts for difference, this would not affect the practice of lowballing, since for the latter it is irrelevant whether the control threshold is achieved by acquisition of shares or by contracts for difference. This could therefore be remedied, in particular, by the measures considered by the Commission, namely the introduction of an additional control threshold and the introduction of a minimum acceptance quota. Several member states have provided for an additional control threshold - with considerable differences in detail. ${ }^{143}$ The City Code is particularly strict, with its Rule 9.1 (b) also obliging such party to issue a mandatory bid who holds between $30 \%$ and $50 \%$ of the voting rights and acquires additional shares (or interests in shares), ${ }^{144}$ and with its Rules 9.3 and 10 further stipulating the condition for each offer - including mandatory bids - that the bidder has to hold at least $50 \%$ of the voting rights after the offer; if this condition is not fulfilled, the bidder is not permitted to acquire the shares offered to it. ${ }^{145}$

In Germany, too, following the takeover of Hocbtief by ACS there were calls for the introduction of another control threshold; they resulted in draft bills proposed by the SPD parliamentary group and of the Federal State of North Rhine-Westphalia ${ }^{146}$ which, however, were not implemented. In the course of the discussion, the conceptional connection has been rightly pointed out between Rule 9.1 (b) and the minimum acceptance quotas stipulated in Rules 9.3, 10 of the Code; 147 in effect, Rule 9.1 (b) of the City Code, which triggers another mandatory bid, thus sanctions a status that in the view of the Code is undesirable. Besides, is

\footnotetext{
142 In more detail, Enriques/Gatti, supra note 128, pp. 24 et seqq.; Kalss, Creeping-in und Beteiligungspublizität nach österreichischem Recht, in Kämmerer/Veil, Übernahme- und Kapitalmarktrecht in der Reformdiskussion (2013), pp. 139, 153 et seqq.; using the example of the takeover of Continental AG by Schaeffler KG Habersack, supra note 137, pp. 817 et seqq. 143 See in more detail Assessment Report, supra note 18, pp. 129 et seqq., further, Merkt, "Creeping in" aus internationaler Sicht, 14 NZG (2011), pp. 561 et seqq.

${ }^{144}$ In this regard, as well as regarding the preceding version, according to which in the case of an acquisition of $1 \%$ per year a new mandatory bid was not necessary, see Crawshay, Mandatory Bids in U.K., in: Veil, Übernahmerecht in Praxis und Wissenschaft (2009), pp. 83, 84 et seqq.; Kershaw, supra note 3, pp. 237 et seqq.

145 Kershaw, supra note 3, pp. 212 et seqq.

146 BT-Drucks. 17/3481 and BR-Drucks. 584/2/10; on this matter, Baums, supra note 140, pp. 2374 et seqq.; Merkt, supra note 143, pp. 566 et seqq.; Tyrolt/Cascante, Pflichtangebotsbefreiung durch Übernahmeangebot und Mindestpreisregelungen, in: Mülbert/Kiem/Wittig, supra note 65, pp. 110, 140 et seqq.

147 Von Bülow, supra note 140, pp. 38 et seqq.; von Falkenhausen, Reformbedarf beim Pflichtangebot gemäß \ 35 WpÜG, 174 ZHR (2010), pp. 293, 298 et seqq.
} 
has been pointed out that the City Code does not contain an obligation for a subsequent improvement in the offer comparable to $\ 31$ para. 5 of the WpÜG, with the consequence that in the case of an off-exchange subsequent acquisition the bidder is not obliged to increase the offer price accordingly; ${ }^{148}$ Rule 9.1 (b) of the City Code therefore aims at making a subsequent acquisition at a higher price unattractive. ${ }^{149}$

Since German law, on the one hand, does not provide for a minimum acceptance quota, but stipulates, on the other hand, that subsequent acquisitions have to result in a price adjustment, a hasty adoption of the British model is not advisable. ${ }^{150}$ Of course, this concern does not oppose the introduction of a second control threshold at the level of European or national law, for example after the model of French, Italian or Austrian law ${ }^{151}$ or upon acquisition of a majority interest ${ }^{152}$. However, given the other concerns about a mandatory MBR set forth about ${ }^{153}$ we should be sceptical of calls to make the rule stricter. In light of this, in the view of this author, both at the European level and at the level of German law no additional control threshold should be introduced; instead, the legislator should rely on the intra-company protective mechanisms (from a German perspective: in particular, on the proper functioning of the law on groups of companies). ${ }^{154}$ The same applies with regard to the introduction of a minimum acceptance quota considered by the Commission.

\section{RESULT}

It is becoming increasingly difficult to justify a mandatory MBR, since the exploitation of the offeree company by the controlling shareholder is more or less excluded by obligations to disclose information, by shareholder activism and by the aforementioned reform of the Shareholder Rights Directive. In view of the foregoing, the MBR should be amended so that it is merely a default rule subject to shareholder-opt out. Furthermore, there is no compelling reason to take steps at the European level in order to prevent low-balling.

\footnotetext{
148 Von Falkenhausen, supra note 147, p. 301.

149 Ibid.

150 Baums, supra note 140 , pp. 2382 et seqq.

151 Under the relevant provisions, a further mandatory bid is required in the case of additional acquisitions of $2 \%$ or, respectively, 3\%, see Tyrolt/Cascante, supra note 146, p. 142.

152 E.g. under French law, cf. Baums, supra note 140, p. 2379.

153 See in more detail above IV. 3., 4.a.

154 To this effect, see also Baums, supra note 140, pp. 2387 et seqq.; von Bülow, supra note 140, pp. 38 et seqq., von Falkenhausen, supra note 147, pp. 298 et seqq.; Tyrolt/Cascante, supra note 146, pp. 142 et seqq.; contrary view: Merkt, supra note 143, pp. 566 et seqq.; at least with this tendency also Hopt, supra note 16, pp. 49 et seqq.
} 